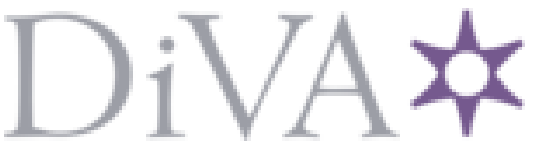

http://www.diva-portal.org

Preprint

This is the submitted version of a paper published in International Journal of Migration, Health and Social Care.

Citation for the original published paper (version of record):

Bergström-Wuolo, M., Dahlström, J., Hertting, K., Kostenius, C. (2018)

My heart has no hurt: The health of young immigrants

International Journal of Migration, Health and Social Care, 14(3): 290-304

https://doi.org/10.1108/IJMHSC-02-2018-0004

Access to the published version may require subscription.

N.B. When citing this work, cite the original published paper.

Permanent link to this version:

http://urn.kb.se/resolve?urn=urn:nbn:se:hh:diva-37689 


\section{eemeraldinsight}

\section{International Journal of Migration, Health and Social Care}

My heart has no hurt: the health of young immigrants

Maya Bergstrom-Wuolo, Josefin Dahlström, Krister Hertting, Catrine Kostenius,

\section{Article information:}

To cite this document:

Maya Bergstrom-Wuolo, Josefin Dahlström, Krister Hertting, Catrine Kostenius, (2018) "My heart has no hurt: the health of young immigrants", International Journal of Migration, Health and Social Care, https://doi.org/10.1108/IJMHSC-02-2018-0004 Permanent link to this document:

https://doi.org/10.1108/IJMHSC-02-2018-0004

Downloaded on: 02 August 2018, At: 20:12 (PT)

References: this document contains references to 74 other documents.

To copy this document: permissions@emeraldinsight.com

Access to this document was granted through an Emerald subscription provided by emerald-srm: 172900 []

\section{For Authors}

If you would like to write for this, or any other Emerald publication, then please use our Emerald for Authors service information about how to choose which publication to write for and submission guidelines are available for all. Please visit www. emeraldinsight. com/ authors for more information.

\section{About Emerald www.emeraldinsight.com}

Emerald is a global publisher linking research and practice to the benefit of society. The company manages a portfolio of more than 290 journals and over 2,350 books and book series volumes, as well as providing an extensive range of online products and additional customer resources and services.

Emerald is both COUNTER 4 and TRANSFER compliant. The organization is a partner of the Committee on Publication Ethics (COPE) and also works with Portico and the LOCKSS initiative for digital archive preservation.

*Related content and download information correct at time of download. 


\title{
My heart has no hurt: the health of young immigrants
}

\author{
Maya Bergstrom-Wuolo, Josefin Dahlström, Krister Hertting and Catrine Kostenius
}

\begin{abstract}
Purpose - The purpose of this paper is to explore health from the perspective of young immigrants in Sweden. Design/methodology/approach - A total of 25 newly arrived young immigrants attending Swedish language classes in northern Sweden participated by drawing and writing open letters. They continued the open-ended sentence "Now l'll draw and describe a day when I was feeling good, that was [...]."

Findings - The phenomenological analysis resulted in three themes: longing to be in control for a better life, searching for power in the good and the bad, and striving for a sense of belonging in the new society. The findings illuminate young immigrants' perspectives of a health-promoting everyday life consisting of agency, reflection and a sense of community. The findings also highlight the young immigrants' experiences when health-promoting aspects are lacking, characterized by disillusionment, anxiety and loneliness. The findings are discussed with health promotion, health literacy and young immigrants in mind.

Practical implications - According to young immigrants, meeting basic needs such as food, sleep and housing is health promoting but easily taken for granted. Being able to have a say in matters concerning everyday life, social inclusion and finding power in memories - positive and negative - can promote health in young immigrants.
\end{abstract}

Originality/value - The young immigrants were able to communicate via drawings and words to overcome language barriers.

Keywords Health promotion, Health, Immigrants, Health literacy, Agency, Qualitative method

Paper type Research paper

\section{Introduction}

Throughout history migration for economic, political and social reasons has been a natural part of global society. According to the IOM (2014) every seventh person in the world is a migrant within or between countries. Due to conflicts in the world, the number of refugees has risen rapidly in recent years and it is estimated that there are $65 \mathrm{~m}$ people on the run from their homeland (Migratonsinfo, 2017). The vast number of refugees from war zones moving to Sweden and other European countries has placed migration policy firmly in the spotlight. Since June 2015, 700,000 refugees have come to Europe (WHO, 2016). According to the European Union (EU) (2016), the number of refugees has put pressure on food, water and housing for refugees in some countries. This especially applies to Greece and Italy as they are usually the first destination for those refugees arriving in the EU (2016). In 2015, 163,000 asylum seekers came to Sweden, double what it was in 2014 (Swedish Migration Agency, 2016). Sweden together with Germany, Hungary, Austria and Italy are the five countries with the highest number of asylum seekers, which represented 75 percent of all EU applications in 2015 (EU, 2016). Approximately 33m of the migrants in 2011 were under 19 years old (IOM, 2013). According to Eriksson-Sjöö et al. (2012), many newly arrived immigrants carry with them difficult life experiences, which can be seen in, for example, sleeping disorders. In a Swedish study with unaccompanied children, school was highlighted as a central health-promoting arena, giving structure to everyday life and facilitating relations with others (Malmsten, 2014). However, according to Hedlund and Cederborg (2015), the children are not treated as agents of their own future by the authorities, and the authors argue that the children need to be assessed on their own terms. Kaukko and
Maya Bergstrom-Wuolo is based at Public Health Center, Norrbotten County Council, Luleå, Sweden.

Josefin Dahlström is Health Counselor in Luleå, Sweden. Krister Hertting is based at the School of Health and Welfare, Halmstad University, Halmstad, Sweden.

Catrine Kostenius is Professor at the Department of Health Sciences, Luleå University of Technology, Luleå, Sweden.

Received 4 February 2018

Revised 12 May 2018

Accepted 29 May 2018

First of all, the authors would like to thank the young immigrants who participated. Thank you to the Head of Education, the School Development Manager and the language teachers for making this study possible. The study was supported by the Swedish National Agency for Education, The Public Health Center at Norrbotten County Council, the Department of Health Science at Luleå University of Technology, and the School of Health and Welfare at Halmstad University. Additionally, the authors appreciate Riksbankens Jubileumsfond - the Swedish Foundations for Humanities and Social Science - enabling this study by their financing of the national Flexit research program. 
Wernesjö (2017) argue that Finland and Sweden have an urgent need to develop the reception and care of unaccompanied children in order to facilitate the participation of unaccompanied children and to address the changing situation. In addition, Wernesjö (2012) suggests that there is a critical need for research on unaccompanied children's life situations based upon exploration of their own perspectives. The purpose of this study was therefore to explore health from the perspective of young immigrants in Sweden.

Coming to a new culture and a new society means a massive transition process, which includes several areas. For individuals, meeting a new society and a new language affects attitudes and identities (Zacheus, 2010). According to Esses et al. (2017), refugees initially need suitable housing and host language learning, followed by (and somewhat overlapping) employment support and opportunities, health support and social connections and civic integration. According to Roberts et al. (2015), immigrants face several challenges based on a lack of language and cultural knowledge about a new society when dealing with, for example, the education system, the healthcare system and the labor market. Further, immigrants also risk meeting discrimination from some parts of society at the same time as they need to adapt to the fact that they are considered a minority group in the new society. Being thought of as a minority group brings the risk of feeling that citizenship status is being lost, and this can lead to a sense of a lack of identity, a lack of cultural belonging and a lack of status in the new society (Papadopoulos et al., 2007). Fang et al. (2015) state that many immigrants have a feeling that they are second-class citizens and are not heard in the new society. The authors argue that immigrants also experience poorer health in the new country. According to Lecerof et al. (2016), mental health is poorer among immigrants compared to the mainstream population in Europe and in Sweden. In particular, refugees suffer more from mental illnesses such as depression and anxiety. Shawel Abebe et al. (2014) argue that the mental illness of refugees can be caused by and aggravated by a variety of negative events including traumatic experiences and acculturative stress. They claim that health varies greatly depending on socio-cultural and economic contexts, gender, generation and social integration. Mental illness has been shown to reduce the quality of life (Baños et al., 2017) and health among new immigrants has been a major challenge in many countries (Shawel Abebe et al., 2014). Lindgren et al. (2012) suggest a more generous policy for access to the healthcare system for asylum seekers.

Health plays an important role in the process of immigrants establishing themselves in society, it is not only a fundamental right but also a prerequisite for participation in society, integration and their ability to develop social networks in the new country (Esses et al., 2017). According to the WHO (1946), "Health is a state of complete physical, mental and social well-being and not merely the absence of disease or infirmity" (p. 1). Fetro (2010) widens the health definition by acknowledging not only physical, mental and social well-being but also existential well-being. WHO (2002) survey regarding self-rated health and quality of life was studied by Melder (2011) who describes existential health using such aspects as the meaning and purpose of life, experiences of awe and wonder, inner peace, hope, optimism and faith. Health literacy is a concept often mentioned in connection to immigrants and refugees (Wångdahl et al., 2015). According to the WHO (2013), "health literacy entails people's knowledge, motivation, and competencies to access, understand, appraise, and apply health information to make judgments and take decisions in everyday life concerning healthcare, disease prevention, and health promotion to maintain or improve quality of life during the life course" (p. 4). Nutbeam (2008) argues that health literacy is essential in order to enable individuals to make healthy lifestyle choices, improve community health and take actions to change public policies related to health. He describes further health literacy on three levels, the first level being the basic ability to achieve and understand health information called functional health literacy. The second level, called interactive health literacy, consists of an individual's capacity, motivation and self-confidence to act independently based on the achieved knowledge. Critical health literacy is the third level which refers to the skills needed to take social and political actions to address determinants of health. According to Kickbusch et al. (2013), health promotion is a tool to increase health literacy which is a key determinant of health. Health promotion aims at strengthening the individual's control over their own health and acts as a guide toward independently improving and maintaining a healthy lifestyle (WHO, 1986). Health promotion efforts which include multiple components - targeted to a specific group and the surrounding factors and arenas that have a significant impact on the individual's everyday life - have proven to be effective (Kobel et al., 2017). 
One of the Sweden's 11 public health goals relates to health promotion within healthcare to promote good health among the population by investing in disease prevention and health promotion (Prop. 2002/03: 35, 2002/2003). Binns et al. (2014) show an improved life expectancy in Australians, in the indigenous and non-indigenous population alike, which according to the authors can be contributed to health promotion interventions. However, they add a note of warning as proposed cutbacks to health promotion and prevention services may rapidly reverse some of these gains. As argued for above, health is a prerequisite for the successful establishment of immigrants in a new society. Ferrera (2017) stresses the importance of initiating health promotion for positive minority youth development, where the youth are involved in the process. Additionally, Wimelius et al. (2017) who study the Swedish reception of unaccompanied refugee children call for research including the voices of the children and youth themselves. Riedel et al. (2011) suggest that "migration programmes should aim at bolstering migrants's sense of coherence (SOC) by identifying resource factors, providing adequate bio-psycho-social resources, and promoting the migrant's ability to comprehend, manage and find meaning in their new society" (p. 563). A person with high SOC will understand the challenge (comprehensibility), believe that resources to cope are available (manageability) and be motivated to cope (meaningfulness) (Antonovsky, 1996). This is supported by Erim et al. (2011), who argue that SOC can be regarded as a strong predictor of depressiveness among immigrants and Ghazinour et al. (2004), who mean that a high SOC in combination with social integration can serve as protectors from mental illness among refugees. O'Tool Thommessen et al. (2015) find the crucial importance of clarifying the complex asylum-seeking process, the protective influence of social support, the importance of educational guidance and participants' strong desire to fit in and move forward with their lives. Further, they suggest informing the practice of supporting asylum-seeking youths' adaptation in host-societies and the need for developing assessment measures and interventions for these groups.

\section{Method}

To capture the young immigrants' experiences of what promotes health an inductive, phenomenological design inspired by van Manen (1997) and Kostenius (2008) was used. According to van Manen (1997), the intention of phenomenological research is to gain a deeper understanding of the nature or meaning of everyday experiences. As the young immigrants can be considered to be experts on their own life experiences, it seemed vital to listen to their voices and involve them in research concerning questions about their health and well-being, although some meaning can be lost in translation (cf. Malmsten, 2014). Inspired by Kostenius (2008), the young immigrants were invited to complete an open letter by drawing and writing to illustrate their experiences. They continued the open-ended sentence "Now l'll draw and describe a day when I was feeling good, that was [...]." Drawings have been used for a number of purposes, for example assessing the development of children (Cherney et al., 2006). According to Alerby (1998), drawings can be, as is the case in this study, a way to gain access to young people's lived experiences. Further, pictures and drawings can offer a deeper understanding of the participants' thoughts (Driessnack, 2005) and provide an insight into a non-verbal world with its own language (van Manen, 1997).

\section{Participants and context}

This study is part of a major development and research project in a municipality in northern Sweden focusing on health-promoting school development, where the fourth author was the scientific leader. The overall aim of the project was to increase pupils' well-being and educational achievement in school. The study reported on in this paper started out as a bachelor's thesis project by the first and second authors focusing on what promotes health in young immigrants in northern Sweden from their own perspectives. Data were analyzed by all authors resulting in the current findings and all authors have been involved in the writing. Approximately 40 percent of the high school students in the participating municipality were newly arrived young immigrants and 57 young people attended Swedish language introduction classes. All of them were invited to participate but 5 of them were not in class the day of the study, so 52 were invited and 25 chose to participate. No information was collected on an individual level, so the following information is about the participating young immigrants on a group level. No information about gender was 
collected due to ethical considerations. The reason for not collecting information about gender was to offer all the participants a high level of confidentiality. The young immigrants who participated were both boys and girls at the age of 15-19 and came from Afghanistan, Sudan, Eritrea, Syria and Iraq. The unaccompanied persons resided in youth homes, the young immigrants who came to Sweden with some or all of their family lived together with their relatives. The young immigrants had arrived approximately 14-16 months earlier and had a varied school background, generally a short education in their home country, with the exception of a few who had never previously attended school.

Data collection and ethical considerations. In February 2017, the participating municipality organized an educational day in the health-promoting school project attended by the first, second and fourth authors. The first and second authors presented the purpose of the study to two teachers who at the time taught the newly arrived immigrants attending the Swedish language introduction classes. The teachers were given oral and written information about the study, as outlined in the Helsinki Declaration (2008). In accordance with Swedish ethical law (SFS 2003:460, 2003), participation was voluntary, and informed consent was to be collected from the participants. The teachers distributed the information letter to the young immigrants attending the Swedish language introduction classes and gave oral information about their participation. They were informed that participation was voluntary and that they could end their participation without consequence. The young immigrants who decided to participate were asked to continue the open-ended sentence "Now I'll draw and describe a day when I was feeling good, that was [...]." The open letters were collected by the teachers and sent to the researcher via mail without any personal data. The researchers assigned the anonymous open letters a number for the sake of presentation. In addition, before the study started it was reviewed by the local ethical committee (2017/128-31).

\section{Data analysis}

The data consisting of drawings and text from the open letters was analyzed by using a hermeneutic phenomenological method inspired by van Manen (1997). The phenomenon in this case is young immigrants' experiences of what promotes health, and the analysis process focused on forming an understanding of this phenomenon. According to van Manen (1997), the analytical process should allow the phenomenon to appear precisely as it is; a free act of "seeing" instead of being governed by certain predetermined rules. The young immigrants' responses have probably been affected by their varying abilities to express their reflections in writing, or by their different interpretations of the task of completing the open letter. Presumably the young immigrants decided which experiences were plausible to reveal in this context, from their perspective (cf. Westling Allodi, 2002). Our process of analysis began with the first, second and fourth authors reading and viewing all the open letters before the first discussion of the results. Reflections were then made and similarities and differences were noted and discussed. The young immigrants' responses were diverse, but similarities were also noted. The similarities and differences that were noticed were then combined into different themes that reflected specific aspects of the young immigrants' visions and thoughts in accordance with van Manen (1997). The analysis continued with the third author joining in the discussions which then focused on illuminating the whole and the individual experiences of all the young immigrants to understand patterns of meaning. The focus was on health from the perspective of the young immigrants as a group, where different nuances surfaced expressed by all or some of the participants. Regardless of how many participants showed a consensus of a specific notion it was regarded meaningful, thus there was a back and forth motion between the groups as a whole or part of the group and the individual expression of health when forming the themes. According to Polit and Beck (2004), the use of quotations enhances a study's credibility, so representative and illustrative drawings and quotations from the open letters were chosen to exemplify the themes, giving voice to the participating young immigrants. The chosen drawings were enhanced with a computer program called Adobe lllustrator, before being added to the results section. According to Driessnack (2005), drawings can be misused if adults disregard children's own words describing their own drawings. Therefore, the captions the young immigrants gave their drawings are used in this paper. 


\section{Results}

The purpose of the study was to explore health from the perspective of young immigrants in Sweden. The phenomenological analysis resulted in three themes: longing to be in control for a better life, searching for power in the good and the bad, and striving for a sense of belonging in the new society. The findings illuminate young immigrants' perspective of a health-promoting everyday life consisting of agency, reflection to find power and a sense of community. The findings also highlight the young immigrants' experiences when health-promoting aspects are lacking, characterized by disillusionment, anxiety and loneliness. This is further explained below.

\section{Theme 1: longing to be in control for a better life}

The young immigrants described fulfiling basic needs for health and well-being such as eating, sleeping and feeling love. In addition, they described activities for a meaningful leisure time (Figure 1). They expressed the need for good self-esteem and room to decide over matters concerning themselves and their lives. The young immigrants appreciated having a say and being able to decide when, where and how something would happen. They emphasized the importance of not feeling restricted in meeting their own basic needs to increase health and well-being. For example, being able to eat and sleep when they saw fit. This freedom to choose was also in connection to social life. One young immigrant wrote "I felt really good when I knew I could meet my family, my friends, relatives and the others [...] whenever I wanted" (participant 3).

The young immigrants described the joy and wonder of achieving something that has long been a dream and into which they have put much effort. One participant described this: "The best thing that has happened in my life is that I passed my driving test and will now buy my dream car that I've longed for" (participant 17). The young immigrants wrote about a sense of freedom that made them feel independent. This could be traveling or earning their own money and not having to worry about future expenses. Taking care of yourself, feeling harmony and inner peace was expressed, as too was feeling content with your body; this was something that the participants emphasized as a positive part of a healthy everyday life. They valued being able to move and exercise. One participant wrote "When I run and move my body, I feel good" (participant 9).

At the same time, as the young immigrants described health-promoting aspects relating to having the power to decide and act they expressed the lack thereof. They described, for example, anxiety about their life situation because the future was unsure and they had the feeling that it was impossible to influence their fate. One young immigrant put words to the disillusionment: "Emigration [...]? Future [...]?" (participant 13). Another wrote "I do not know what will happen" (participant 12) along with words like "worried, sad, broken, alone." The young immigrants also

Figure 1 The basic needs are important (participant 23)

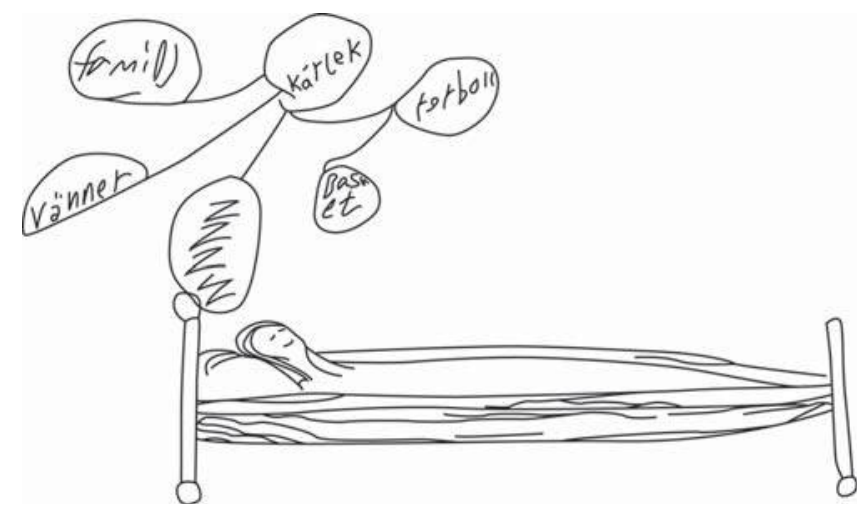

Note: The text in the drawing includes the following words: family, friends, love, basketball, soccer, Zzzzz 
expressed their wish to improve their life situation, which at the moment made them unable to feel good. The longing for a better life with hopefulness and a sense of optimism was expressed with the words "That my heart has no hurt" and a drawing of a heart with a band-aid (Figure 2).

\section{Theme 2: searching for power in the good and the bad in life}

The young immigrants wrote about the importance of being able to reflect by themselves and think back on happy memories or dream of a positive future. Daring to dream about traveling or being able to stay in Sweden was an experience that gave strength and motivation, conveying a sense of meaning and purpose in life. The young immigrants expressed having a good feeling when remembering a deceased parent or relative (Figure 3). They described the joy in the most recent conversation on the phone with a relative. This was described by one young immigrant: "I called my mom yesterday. She became happy when I called" (participant 21) (Figure 4). To feel empowered by giving and receiving love and appreciation was expressed in connection to relationships.

The young immigrants described how, after some time, difficult memories gave them strength. One young immigrant described the dangerous life of being a boat refugee from another angle: "I felt good when I went by boat from Turkey to Greece" (participant 22). The journey to Sweden gave the

\section{Figure 2 A participant's wish: "That my heart has no hurt" (participant 10)}

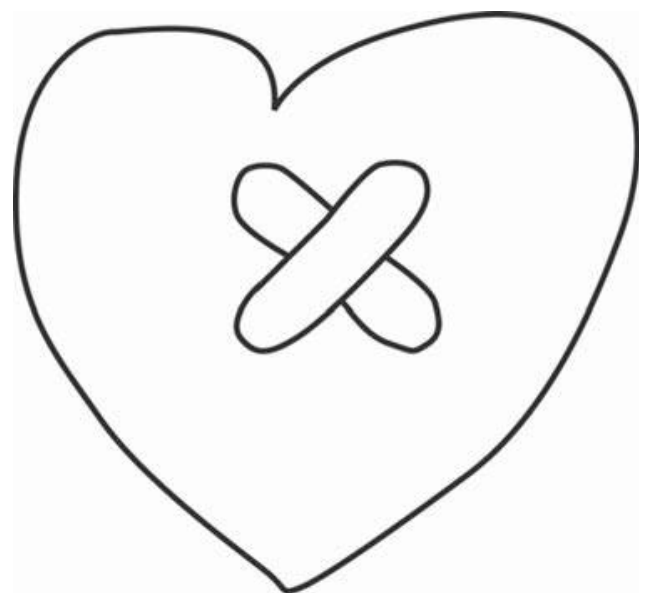

Figure 3 The memory of a deceased parent gives strength (participant 10)

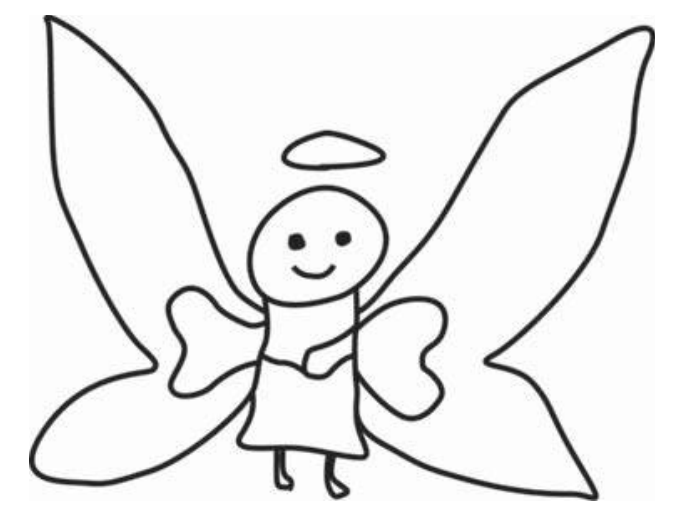




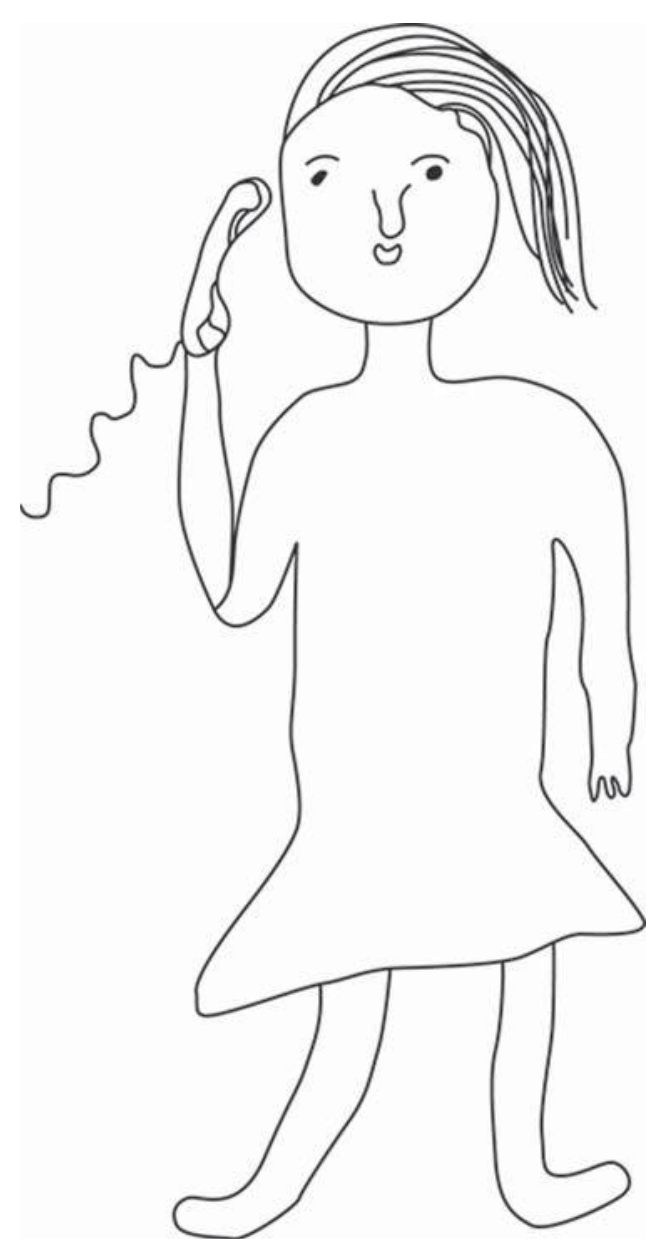

young immigrants new perspectives and insights. For example, that life was easier in the country of origin: "There was a time I thought I was free from problems and worries [...]" (participant 25). One young immigrant explained the importance of remembering a special occasion of shared joy and happiness with a loved one and how these memories gave a positive feeling and security, "Remembering her smile makes me think how great it was and how happy I felt" (participant 4).

At the same time, as the young immigrants described health-promoting aspects when finding power in good memories, when handling tough situations they expressed the opposite. Experiences of good health and well-being were described as scarce or non-existent. The young immigrants explained how feelings of anxiety, sadness and loneliness were hard to overcome (Figure 5). One young immigrant wrote "I never feel good" (participant 18).

\section{Theme 3: striving for a sense of belonging in the new society}

Participating in a group gave the young immigrants a sense of being part of a context. They described this in terms of being part of a sports team or sharing togetherness with friends and family. One young immigrant wrote: "About 3 months ago we were [...] in the cup competition where we won and I became happy" (participant 24). The young immigrants described how being needed and appreciated by others was important for their well-being, which the following quote illustrates: "Helping others when they need a hand to help" (participant 4). Making someone else happy was pleasing for the young immigrants. The fellowship with others was described in 


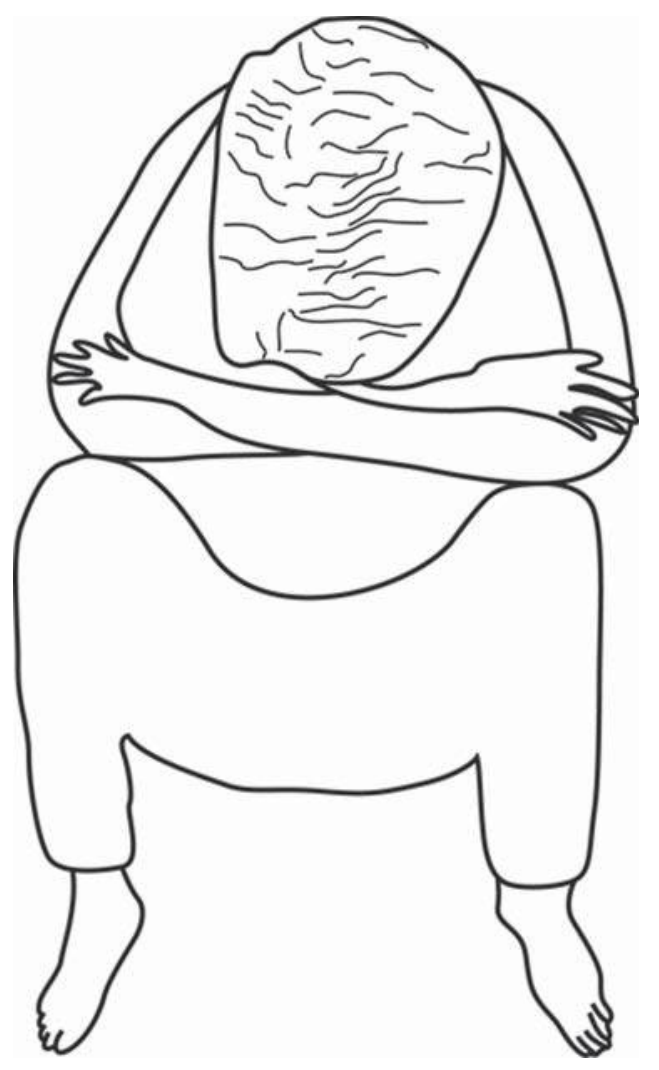

relation to both family and friends and about being part of something greater. The young immigrants described how a sense of belonging was important for their health and well-being. One of the young immigrants wrote: "family together and in peace" (participant 10).

The young immigrants gave examples of a variety of activities that they found promoted health such as working out at the gym, soccer, basketball and volleyball. According to the young immigrants being physically active was good for both the physical aspects of caring for their body and also in relation to sharing time with others, being part of a team. The sports arenas were described as places to meet and to get to know new people who came to mean a lot to them, connecting in fellowship and allowing them to be happy and laugh together. Some of the young immigrants brought with them experiences of sports which constituted a goal to aim for in their new context in Sweden. One participant wrote: "[...] me and my friends played soccer in Afghanistan one evening" (participant 15) (Figure 6).

At the same time, as the young immigrants described health-promoting aspects when being part of a fellowship or a team, they also described loneliness. The young immigrants expressed sadness and dejection in concerns about them fitting in and being included in their new situation. One young immigrant wrote: "I was happy when I was with my family [...] Now I'm alone" (participant 19).

\section{Discussion of method}

According to van Manen (1997), phenomenological research is attuned toward caring and thoughtfulness which can be a way to meet the challenges of health promotion efforts aimed at young immigrants in Sweden. The health of young immigrants is considered deficient (Wimelius et al., 2017) and giving voice to this group of young people can be a start. The language may have had a limiting effect when young immigrants with rudimentary Swedish language skills were 


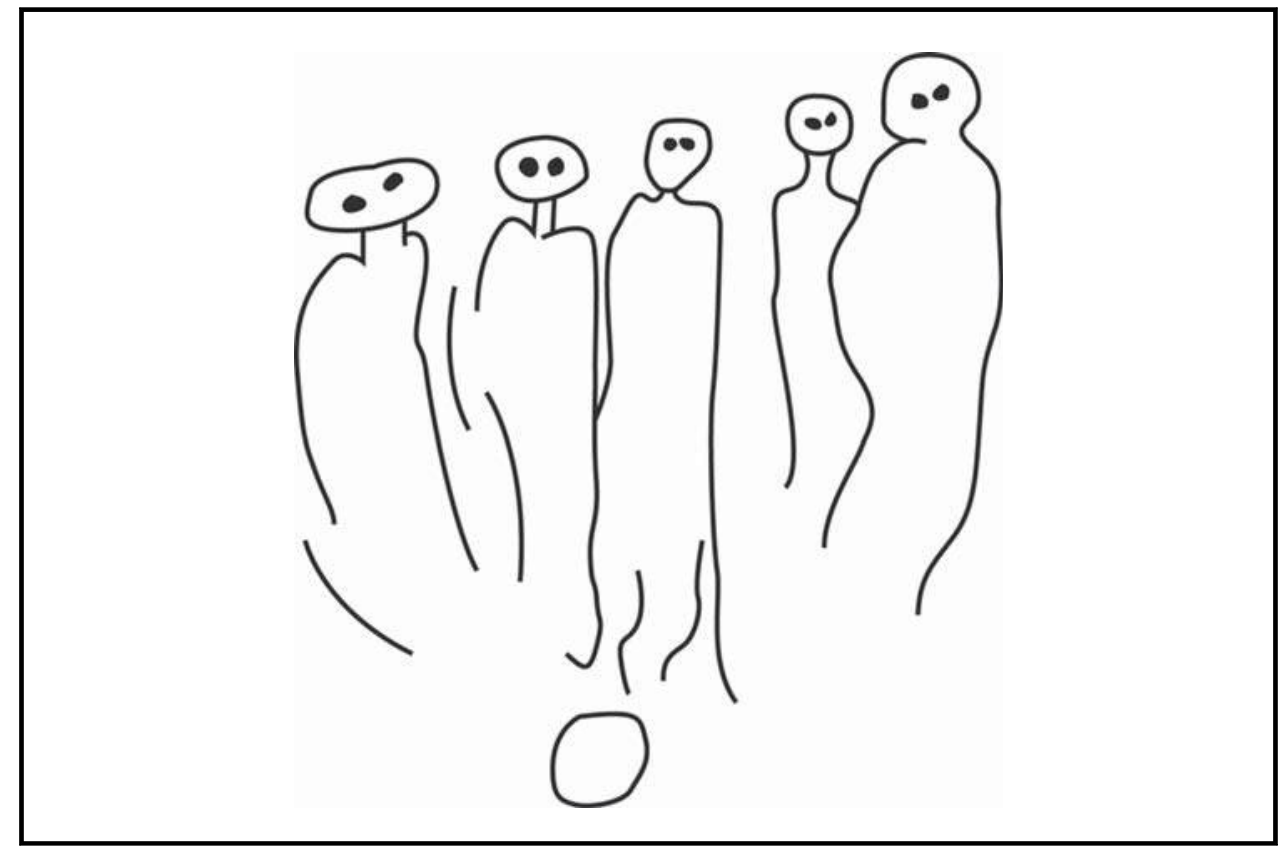

asked to write in Swedish. However, the possibility to both draw and write gave the participating young immigrants more freedom to express themselves (cf. Driessnack, 2005). Thus, the young immigrants were able to communicate via drawings and words to overcome language barriers. If the chance had been given to talk to the young immigrants, there might have been an opportunity to deepen the understanding. However, the high level of confidentiality, not having to reveal any personal information, may have increased the freedom of expression. Driessnack (2005) points at a deficit in using drawings, if researchers disregard children's own interpretation of their drawings. With this in mind we let the young immigrants draw and also use their own words to describe their drawing. One can view the number of 25 participants as too few and therefore a limitation of the study. However, according to Kvale and Brinkmann (2014), the number of participants in qualitative research can be considered sufficient when findings, as is the case in this study, resulted in themes showing a wide picture of experiences. The participants came from Afghanistan, Sudan, Eritrea, Syria and Iraq with unique life stories and different journeys ending up in Sweden. The themes illuminate a wide range of examples that include both positive and negative experiences voiced by these young immigrants living in the northern part of Sweden. Each theme has a distinct direction but they are, at the same time, somewhat overlapping. However, we have emphasized internal validity, which means making conscious decisions from basic assumptions, to design, data collection, interpretation and reporting empirical findings (Kvale, 2007; Miles and Huberman, 1994). This requires, according to Whittenmore et al. (2001), authenticity and integrity, which has been of importance in this process. Internal validity is a prerequisite for transferability (Guba and Lincoln, 1981; Polit and Beck, 2004), which means that the accuracy of the results has possibilities to be transferred to other, but similar, contexts than the current studied. To strengthen credibility, we have used quotations from the participating young migrants in the presentation of the results in line with Guba and Lincoln (1981). Despite the limitations in this study, the findings may be applicable to, and have currency in other similar contexts, an argument supported by, for instance, Kvale (2007) and Yin (1994).

\section{Discussion of findings}

Although the open letter asked for health-promoting experiences, there were participants who could not respond to the open question in the letter and instead wrote about an existence filled 
with disillusionment, anxiety and loneliness. This can be compared to mental health issues described by Fang et al. (2015). The young immigrants expressed anxiety connected to the family they had left in their home country, uncertainty in the asylum process and the possibility of staying in Sweden. According to Sundell et al. (2016), mental health is poorer among the newly immigrated than Swedish-born people. According to Baily (2017), poor mental health has primarily been identified in unaccompanied children and adolescents who display post-traumatic stress, self-harm and sleep disorders. Mental illness has been shown to reduce the quality of life (Baños et al., 2017), which was also expressed by the participants. Shawel Abebe et al. (2014) argue that mental illnesses of refugees can be exacerbated by factors that may affect the refugee and asylum process. A promotion perspective could be a part of future efforts, as it can strengthen existing mental health among new arrivals (Celano et al., 2017). The suggestion by Lindgren et al. (2012) to have generous access to the healthcare system for asylum seekers seems relevant.

The findings point to the young immigrants search for power in memories - whether good or bad. Remembering and reflecting over people and events in their lives was a source of power and strength to use in their daily lives to increase health and well-being. The young immigrants felt gratitude, for example, about the journey to Sweden, about being able to attend school or being part of a community. This is similar to the description of positive psychology by Celano et al. (2017) as reinforcing mental well-being by focusing on positive factors such as gratitude, personal strength and solidarity. Another connection can be made to Melder (2011) who finds existential dimensions of health in the WHO's documents concerning quality of life aspects related to spirituality, religiousness and personal beliefs. Among the existential aspects of health presented by Melder (2011), the young immigrants in this study described the meaning and purpose of life, experiences of awe and wonder, inner peace, hope and optimism. The young immigrants expressed how them being able to set aside the tough times and dream and hope for a bright future was considered important. This way of thinking is in line with Antonovsky's (1979) SOC, which can support young immigrants and refugees to handle problems and challenges in life despite of stressful and traumatic experiences (Erim et al., 2011; Ghazinour et al., 2004). To ensure effective mental health promotion, Riedel et al. (2011) argue for supporting migrants' SOC emphasizing inclusion strategies to overcome the barriers that inhibit migrants' choices and ability characterized by an understanding of migrant values, preferences and resources. The young immigrants have had difficult experiences and bad memories. However, some of them used these life experiences as something positive to help them move forward in life. According to Knowlden et al. (2012), an SOC and hardiness can be seen in the ability to endure and conquer difficult circumstances and assess threatening situations as less stressful. They go on to explain that young people with this ability exhibit a greater degree of control and perseverance and can better meet the challenges of life. The young immigrants' experiences of making bad memories useful can be compared with Werner and Smith's (2001) description of psychological resilience as an ability to, in spite of highly adverse conditions, successfully adopt to life tasks. Additionally, one interpretation of the young immigrants' experiences of finding balance in their lives in spite of life challenges is similar to resilience as described by Masten (2013). Besides, the specific stressful situation of being a refugee certain factors, such as social support, a sense of belonging and feelings of success and achievement can promote resilience and serve universal needs of children and adolescents, regardless of background and experience (Shoshani et al., 2014, 2016).

The findings bring forth how the young immigrants in this study longed to be in control and be able to make up their own mind and have the opportunity to choose according to their wishes. If they were able to they would choose to stay in Sweden and not have to worry about their asylum status. They described health-promoting aspects of everyday life characterized by freedom to be able to decide where and how to do something and when to spend time with loved ones. This feeling of control over their own existence can be compared to the WHO's (1986) definition of health promotion as "the process of enabling people to increase control over, and to improve, their health" (p. 1). Cyril et al. (2016) connect empowerment, a term commonly used with health promotion, to the individual's agency and autonomy. They go on to explain that the empowerment process is about the 
individual being encouraged to, under guidance, take control of his or her life and overcome feelings of powerlessness and lack of influence. Unfortunately, Hedlund and Cederborg (2015) find that legislators enact reforms of importance for unaccompanied children without considering them as agents of their own future, with their own motives and reasons to seek asylum. Therefore, in order to meet the need for autonomy expressed by the young immigrants, the Children's Convention should be a priority in health-promoting activities as it clearly states that children have the right to express their opinion on all matters that concern them (UNICEF, 2009). The young immigrants in this study express that being able to have control over their lives and feeling successful was a key aspect of well-being. According to Fang et al. (2015), newly arrived immigrants feel that their opinions come second and their voices are not heard in society. The young immigrants described that if they could choose they would participate in community-based activities. This is in line with Kaukko and Wernesjö (2017) who find that the complementary relationship between unaccompanied children and adults in their new home country can be a resource enabling children's participation into the new society. In addition, Fredriksson et al. (2018) mean that youth centers can offer meaningful leisure-time opportunities in multicultural neighborhoods and serve as health promotion settings.

The findings highlight that physical activity was experienced as health promoting by the young immigrants. Physical activity reduces symptoms of depression (Parker et al., 2016) and can have a good effect on child and youth self-esteem (Ekeland et al., 2005). As mental illness is more common in people born abroad than in people born in Sweden (Lecerof et al., 2016), health promoting efforts encouraging physical activity targeted at the young immigrant group may contribute to reduced mental health problems in this group. However, there are social, economic and linguistic factors that influence how physical activity is understood, designed and practiced (Wieland et al., 2015). Civil society and sports clubs can play an important role in inclusion (Whitley et al., 2016), but this is a perspective that needs to be further investigated, so that health promotion efforts can be adapted to the entire group of new immigrants (Hertting and Karlefors, 2013). The participants did mention being part of a sports team offered a sense of belonging to a community, which is supported by Whitley et al. (2016). In other words, school and leisure time increases participation, community building, and the young immigrants learn the Swedish language faster. Similarly, Wernesjö (2015) finds that although the belonging and feelings of home may be challenged for unaccompanied children by exclusionary processes and by being positioned as a stranger the young people still construct some kinds of belonging and feelings of home based on the social relationships and places available to them.

Finally, the findings illuminate young immigrants' perspective of a health-promoting everyday life consisting of agency, reflection to find power and a sense of community. This is in line with Ferrera (2017) who stresses the importance of initiating health promotion for positive minority youth development, where the youth are involved in the process. Based on these findings, one suggestion for health promotion efforts is prioritizing activities that help promote an individual's health literacy on all levels - functional health literacy, interactive health literacy and critical health literacy (Nutbeam, 2008). Kostenius and Bergmark (2016) point out that increased health literacy provides youth with the tools to interpret and understand health information and also include action readiness to use health information and make healthy choices. However, young immigrants as a group are heterogeneous and information and health promotion efforts must be individualized. Therefore, in line with Paakkari and Paakkari (2012), we suggest presenting young immigrants with an opportunity to formulate their own views about their health validating themselves as having agency in their own lives which can increase their knowledge about health and thus help them become more health literate. According to the young immigrants in this study, social support was crucial for their health and well-being. This can be connected to the suggestion by O'Tool Thommessen et al. (2015) about the potential value of mentoring schemes supporting asylum-seeking youths' adaptation in host-societies. Future research can very well examine this possible strategy to increase social support. Further, building on the studies by Riedel et al. (2011) and Wimelius et al. (2017), we suggest future research to examine how young immigrants' health is affected by taking part in health promotion efforts aiming at integration and acculturation. 


\section{References}

Alerby, E. (1998), "Att fånga en tanke. En fenomenologisk studie av barns och ungdomars tänkande kring miljö (To catch a thought. A phenomenological study of children's and youth's thoughts about the environment)", doctoral dissertation, Department of Pedagogy and Didactics, Luleå University of Technology.

Antonovsky, A. (1979), Health, Stress and Coping: New Perspectives on Mental and Physical Well-Being, Jossey-Bass, San Francisco, CA.

Antonovsky, A. (1996), "The salutogenic model as a theory to guide health promotion", Health Promotion International, Vol. 11 No. 1, pp. 11-18.

Baily, C.D.R. (2017), "Investigating the mental health needs of unaccompanied immigrant children in removal proceedings: a mixed methods study”, Doctoral thesis, Graduate School of Arts and Sciences, Colombia University, New York NY.

Baños, R.M., Etchemendy, E., Mira, A., Riva, G., Gaggioli, A. and Botella, C. (2017), "Online positive intervention to promote well-being and resilience in the adolescent population: a narrative review", Frontiers in Psychiatry, Vol. 8 No. 10, pp. 1-9.

Binns, C., Howat, P. and Jancey, J. (2014), "Health promotion success in Australia and a note of warning", Health Promotion Journal of Australia, Vol. 25 No. 3, pp. 157-9.

Celano, C.M., Beale, E.E., Mastromauro, C.A., Stewart, J.G., Millstein, R.A., Auerbach, R.P. and Huffman, J.C. (2017), "Psychological interventions to reduce suicidality in high-risk patients with major depression: a randomized controlled trial", Psychological Medicine, Vol. 47 No. 5, pp. 810-21.

Cherney, I., Seiwert, C., Dickey, T. and Flichtbeil, J. (2006), "Children's drawings: a mirror to their minds", Educational Psychology, Vol. 26 No. 3, pp. 157-9.

Cyril, S., Smith, B.J. and Renzaho, A.M.N. (2016), "Systematic review of empowerment measures in health promotion", Health Promotion International, Vol. 31 No. 4, pp. 809-26.

Driessnack, M. (2005), "Children's drawings as facilitators of communication: a meta-analysis", Journal of Pediatric Nursing, Vol. 20 No. 6, pp. 415-23.

Ekeland, E., Heian, F., Hagen, K. and Coren, E. (2005), "Can exercise improve self-esteem in children and young people? A systematic review of randomised control trials", British Journal of Sports Medicine, Vol. 39 No. 11 , pp. $792-8$.

Eriksson-SjöÖ, T., Cederberg, M., Östman, M. and Ekblad, S. (2012), "Quality of life and health promotion intervention - a follow up study among newley-arrived Arabic-speaking refugees in Malmö, Sweden", International Journal of Migration, Health and Social Care, Vol. 8 No. 3, pp. 112-26.

Erim, Y., Morawa, E., Atay, H., Aygün, S., Gökalp, P. and Senf, W. (2011), "Sense of coherence and depression in the framework of immigration: Turkish patients in Germany and in Turkey", International Review of Psvchiatry, Vol. 23 No. 6, pp. 542-9, doi: 10.3109/09540261.2011.637908.

Esses, V.M., Hamilton, L.K. and Gaucher, D. (2017), "The global refugee crisis: empirical evidence and policy implications for improving public attitudes and facilitating refugee resettlement", Social Issues and Policy Review, Vol. 11 No. 1, pp. 78-123.

European Union (2016), EU och flyktingkrisen [EU and the Refugee Crisis], European Commission, Luxembourg.

Fang, M.L., Sixsmith, J., Lawthom, R., Mountain, I. and Shahrin, A. (2015), "Experiencing 'pathologized presence and normalized absence': understanding health related experiences and access to health care among Iraqi and Somali asylum seekers, refugees and persons without legal status", BMC Public Health, Vol. 15 No. 923, pp. 1-12.

Ferrera, M.J. (2017), "Integrating principles of positive minority youth development with health promotion to empower the immigrant community: a case study in Chicago", Journal of Community Practice, Vol. 25 No. 3/4, pp. 504-23, available at: https://doi.org/10.1080/10705422.2017.1354241

Fetro, J. (2010), "Health-literate youth: evolving challenges for health educators", American Journal of Health Education, Vol. 41 No. 5, pp. 258-64.

Fredriksson, I., Geidne, S. and Eriksson, C. (2018), "Leisure-time youth centers as health-promoting settings: experiences from multicultural neighborhoods in Sweden", Scandinavian Journal of Public Health, Vol. 46 No. 20, pp. 72-9. 
Ghazinour, M., Richter, J. and Eisemann, M. (2004), "Quality of life among Iranian refugees resettled in Sweden”, Journal of Immigrant Health, Vol. 6 No. 2, pp. 71-81.

Guba, E. and Lincoln, Y. (1981), Effective Evaluation, Jossey Bass, San Francisco, CA.

Hedlund, D. and Cederborg, A.-C. (2015), "Legislators' perceptions of unaccompanied children seeking asylum", International Journal of Migration, Health and Social Care, Vol. 11 No. 4, pp. 239-52.

Helsinki Declaration (2008), WMA Declaration of Helsinki - Ethical Principles for Medical Research Involving Human Subject, available at: www.wma.net/policiespost/wma-declaration-of-helsinki-ethical-principles-formedicalresearch-involving-human-subjects/ (accessed July 12, 2018).

Hertting, K. and Karlefors, I. (2013), "Sport as a context for integration: newly arrived immigrant children in Sweden drawing sporting experiences”, International Journal of Humanities and Social Science, Vol. 3 No. 18, pp. 35-44.

IOM (2013), The Migration of Children in ACP Countries: Of Their Own Free will or Involuntary?, International Organization for Migration, Geneva.

IOM (2014), A New Global Partnership for Development: Factoring in the Contribution of Migration, International Organization for Migration, Geneva.

Kaukko, M. and Wernesjö, U. (2017), "Belonging and participation in liminality: unaccompanied children in Finland and Sweden”, Childhood, Vol. 24 No. 1, pp. 7-20.

Kickbusch, I., Pelikan, J., Apfel, F. and Tsouros, A. (2013), Health Literacy the Solid Facts, World Health Organization Regional Office for Europe, Copenhagen.

Knowlden, A.P., Sharma, M., Kanekar, A. and Atri, A. (2012), "Sense of coherence and hardiness as predictors of the mental health of college students", International Quarterly of Community Health Education, Vol. 33 No. 1, pp. 55-68.

Kobel, S., Wartha, O., Wirt, T., Dreyhaupt, J., Lämmle, C., Friedemann, E.-M. and Steinacker, J.M. (2017), "Design, implementation, and study protocol of a kindergarten-based health promotion intervention", BioMed Research International, p. 9, available at: https://doi.org/10.1155/2017/4347675

Kostenius, C. (2008), "Giving voice and space to children in health promotion", Doctoral thesis. Luleå University of Technology, Luleå, Sweden.

Kostenius, C. and Bergmark, U. (2016), “The power of appreciation: promoting schoolchildren's health literacy”, Health Education, Vol. 116 No. 6, pp. 611-26.

Kvale, S. (2007), Doing Interviews, Sage Publications, Thousand Oaks, CA.

Kvale, S. and Brinkmann, S. (2014), Den kvalitativa forskningsintervjun [The Qualitative Research Interview], Studentlitteratur, Lund.

Lindgren, J., Ekblad, S., Asplund, M., Irestig, R. and Burström, B. (2012), "Mental ill health among asylum seekers and other immigrants in Sweden", International Journal of Migration, Health and Social Care, Vol. 8 No. 4, pp. 167-79.

Malmsten, J. (2014), "Unaccompanied children living in transitional houses - voices from Sweden", International Journal of Migration, Health and Social Care, Vol. 10 No. 1, pp. 18-35.

Masten, A.S. (2013), "Risk and resilience in development", in Zelazo, P. (Ed), The Oxford Handbook of Developmental Psychology, 2nd ed., Vol. 2, Oxford University Press, New York NY, pp. 579-607.

Melder, C. (2011), "Vilsenhetens epidemiologi. En religionspsykologisk studie i existentiell folkhälsa [The epidemiology of lost meaning. A study in psychology of religion and existential public health in a Swedish context]", Psychologia et sociologia religionum 25, Doctoral thesis, Uppsala University, Uppsala.

Migratonsinfo (2017), Flyktingar i världen [Migrants in the world], available at: www.migrationsinfo.se/ migration/varlden/flyktingar-i-varlden/ (accessed February 4, 2018).

Miles, M.B. and Huberman, A.M. (1994), Qualitative Data Analysis, 2nd ed., Sage Publications, London.

Nutbeam, D. (2008), “The evolving concept of health literacy”, Social Science and Medicine, Vol. 67 No. 12, pp. 2072-8.

O'Tool Thommessen, S.A., Corcoran, P. and Todd, B. (2015), "Experiences of arriving to Sweden as an unaccompanied asylum-seeking minor from Afghanistan: an interpretative phenomenological analysis", Psychologv of Violence, Vol. 5 No. 4, pp. 374-83. 
Paakkari, L. and Paakkari, O. (2012), "Health literacy as a learning outcome in schools", Health Education, Vol. 112 No. 2, pp. 133-52.

Papadopoulos, I., Lees, S., Lay, M. and Gebreheiwot, A. (2007), "Ethiopian refugees in the UK: migration, adaption and settlement experiences and their relevance to health", Ethnicity and Health, Vol. 9 No. 1, pp. 55-73.

Parker, A.G., Hetrick, S.E., Jorm, A.F., Mackinnon, A.J., McGorry, P.D., Yung, A.R. and Purcell, R. (2016), "The effectiveness of simple psychological and physical activity interventions for high prevalence mental health problems in young people: a factorial randomised controlled trial”, Journal of Affective Disorders, Vol. 12 No. 76 , pp. 200-9.

Polit, D.F. and Beck, C.T. (2004), Nursing Research. Principles and Methods, Lippincott Williams and Wilkins, Philadelphia, PA.

Prop. 2002/03: 35 (2002/2003), "Mål för folkhälsan [Goals for public health]", available at: www.regeringen. se/contentassets/04207325e75943408c69a55643ea1d3e/mal-for-folkhalsan (accessed February 4, 2018).

Riedel, J., Weismann, U. and Hannich, H.-J. (2011), "An integrative theoretical framework of acculturation and salutogenesis", International Review of Psychiatry, Vol. 23 No. 6, pp. 555-64.

Roberts, L.R., Mann, S.K. and Montgomery, S.B. (2015), "Depression, a hidden mental health disparity in an Asian Indian immigrant community", International Journal of Environmental Research and Public Health, Vol. 13 No. 1, pp. 1-17, doi: 10.3390/ijerph1310027.

SFS 2003:460 (2003), "Lag om etikprövning av forskning som avser människor [Law on ethical approval of research on human beings]", available at: www.notisum.se/rnp/SLS/LAG/20030460 (accessed February 4, 2018).

Shawel Abebe, D., Lien, L. and Harsløf Hjelde, K. (2014), "What we know and don't know about mental health problems among immigrants in Norway", Journal of Immigrant and Minority Health, Vol. 16 No. 1, pp. 60-7.

Shoshani, A., Nakash, O., Zubida, H. and Harper, R. (2014), "Mental health and engagement in risk behaviors among migrant adolescents in Israel: the protective functions of secure attachment, self esteem, and perceived peer support", Journal of Immiarant \& Refugee Studies, Vol. 12 No. 3, pp. 233-49, available at: (http://dx.doi.org/10.1080/15562948.2013.827769)

Shoshani, A., Nakash, O., Zubida, H. and Harper, R.A. (2016), "School engagement, acculturation, and mental health among migrant adolescents in Israel”, School Psychology Quarterly, Vol. 31 No. 2, pp. 181-97.

Sundell Lecerof, S., Stafström, M., Westerling, R. and Östergren, P.-O. (2016), "Does social capital protect mental health among migrants in Sweden?", Health Promotion International, Vol. 31 No. 3, pp. 644-52.

Swedish Migration Agency (2016), Årsredovisning 2015 Swedish Migration Agency, Swedish Migration Agency, Norrköping.

UNICEF (2009), Barnkonventionen [The Convention on the Rights of the Child], UNICEF, Stockholm.

van Manen, M. (1997), Researching Lived Experience: Human Science for an Action Sensitive Pedagogy, Althouse, London.

Wångdahl, J., Lytsy, P., Mårtensson, L. and Westerling, R. (2015), "Health literacy and refugees' experiences of the health examination for asylum seekers - a Swedish cross-sectional study", BMC Public Health, Vol. 15 No. 1162, pp. 1-13, doi: 10.1186/s12889-015-2513-8.

Werner, E. and Smith, R. (2001), Journeys from Childhood to Midlife: Risk, Resilience and Recovery, Cornell University Press, Ithaca, NY and London.

Wernesjö, U. (2012), “Unaccompanied asylum-seeking children: whose perspective?", Childhood, Vol. 19 No. 4, pp. 495-507.

Wernesjö, U. (2015), "Landing in a rural village: home and belonging from the perspectives of unaccompanied young refugees", Identities: Global Studies in Culture and Power, Vol. 22 No. 4, pp. 451-67.

Westling Allodi, M. (2002), "Children's experiences of school: narratives of Swedish children with and without learning difficulties", Scandinavian Journal of Educational Research, Vol. 46 No. 2, pp. 181-205.

Whitley, M.A., Coble, C. and Jewell, G.S. (2016), "Evaluation of a sport-based youth development programme for refugees", Leisure/Loisir, Vol. 40 No. 2, pp. 175-99. 
Whittenmore, R., Chase, S.K. and Mandle, C.L. (2001), "Validity in qualitative research", Qualitative Health Research, Vol. 11 No. 4, pp. 522-37.

WHO (1946), Official Records of the World Health Organization, No. 2, International Organization for Migration, Geneva, Switzerland.

WHO (1986), The Ottawa Charter, International Organization for Migration, Geneva, Switzerland.

WHO (2002), "World health organization WHOQOL-SRPB field-test instrument", Department of Mental Health and Substance Dependence Geneva, Switzerland, available at: www.who.int/mental_health/media/en/622. pdf (accessed February 4, 2018).

WHO (2013), Health Literacy. The Solid Facts, World Health Organization, Geneva, available at: www.euro. who.int/_data/assets/pdf_file/0008/190655/e96854.pdf (accessed May 1, 2018).

WHO (2016), World Health Statistics 2016 - Monitoring Health for the SDGs Sustainable Development Goals, World Health Organization, Geneva, Switzerland.

Wieland, M., Tiedje, K., Meiers, S., Mohamed, A., Formea, C., Ridgeway, J. and Sia, I. (2015), "Perspectives on physical activity among immigrants and refugees to a small Urban community in Minnesota", Journal of Immigrant and Minority Health, Vol. 17 No. 1, pp. 263-75.

Wimelius, M., Eriksson, M., Isaksson, J. and Ghazinour, M. (2017), "Swedish reception of unaccompanied refugee children - promoting integration?", International Migration and Integration, Vol. 18 No. 1, pp. 143-57.

Yin, R.K. (1994), Case Study Research: Design and Methods, Sage, Thousand Oaks, CA.

Zacheus, T. (2010), "The significance of sport and physical activity during the acculturation and integration process of immigrants in Finland - the experts' view”, European Journal of Sports and Society, Vol. 7 No. 2, pp. 155-66.

\section{Further reading}

Alerby, E. (2000), "A way of visualising children's and young people's thoughts about the environment: a study of drawings", Environmental Education Research, Vol. 6 No. 3, pp. 205-22.

\section{Corresponding author}

Catrine Kostenius can be contacted at: catkos@|tu.se

For instructions on how to order reprints of this article, please visit our website:

www.emeraldgrouppublishing.com/licensing/reprints.htm

Or contact us for further details: permissions@emeraldinsight.com 